\title{
Woman wants dead fiancé's baby: who owns a dead man's sperm
}

\section{Spriggs}

Woman who sought permission to retrieve dead fiancé's sperm should have been allowed to do so.

$\mathrm{S}$ imone Baker and Andrew Clough met six years ago. They were getting married in April 2003 and they both wanted to have children. They had already picked out names, had decorated a room in their home as a nursery and changed their health insurance cover to "family". ${ }^{1-3}$

On New Year's Eve Ms Baker saw her fiancé slip and fall to his death at the Roaring Meg Falls in an isolated part of far North Queensland. In the days that followed, Ms Baker made an emergency application to the Queensland Supreme Court to harvest and freeze her fiancé's sperm so she could carry out their wish to have their child. Both families were supportive of Ms Baker in her desire to have her dead fiancé's child. ${ }^{4}$

The court denied Ms Baker's request and the judgment came seven days after the man's death-the last day that pathologists could have removed the sperm. Mr Clough had not given specific written consent for his sperm to be harvested in the event of his death although he had consented to organ donation..$^{2-4}$ The judge said there was no precedent for ruling in Ms Baker's favour. ${ }^{3-5}$ In Queensland, it is a criminal offence to "interfere with the body of a dead person without lawful justification" and "lawful justification" requires consent prior to death for "specific use of body tissue". ${ }^{4}$

In some instances, however, the use of human tissue and organs after death without specific consent is allowed. Tissue can be removed for transplantation and "other therapeutic" or "medical and scientific purposes". And, the next of kin can refuse consent even if the dead person consented prior to death. In these situations the family are the "actual donors". *6

Nevertheless, it is reasonable to ask whether genetic tissue is in some way special and different from organs.

If we are thinking in terms of the dead person's interests it is not clear why genetic tissue should be treated differently. John Harris describes concern for the destiny of male gametes as an "overly precious attitude" not "reflected in custom or practice" given that "men are notorious for leaving their gametes behind in all sorts of

\section{Abstract}

The Brisbane Supreme Court has denied an Australian woman's request to harvest and freeze her dead fiancé's sperm for future impregnation. After she was denied access to the sperm, the woman learnt that her fiancé may have been a sperm donor and she began checking to find out if his sperm was still available. Given what we know, there is a good ethical argument that the woman should have access to the sperm and should be allowed to have her dead fiancé's child.

Another aspect of this case is that it illustrates the way in which ethics, law, and personal opinion can differ.

places, some of which may well result in the creation of life". And, they "almost always" do this without "counselling, formal consent, and time for reflection, and usually without missing them...".

After the court's decision, Ms Baker learnt that her fiancé might have donated sperm when he was a university student. The university he attended had a campaign "where you could donate sperm and get money for it". A university spokesperson said they were trying to clarify whether the dead man had donated sperm for research purposes or for a fertility programme. It was "extremely unlikely" the spokesperson added, for a donation made 10 years ago for research or for fertility purposes to be available still. Such donations "would most likely be used at the time of donation" and "the hospital or university would have then owned [the sperm]" if the donor was paid for it. ${ }^{8}$ "

In terms of consent, if Mr Clough had donated his sperm for fertility purposes, given what we know, there seems to be no good ethical arguments for denying Ms Baker access to her dead fiancé's sperm.

If the sperm is still available Ms Baker could access her dead fiancé's sperm. If she is eligible to receive donor sperm, she could possibly identify Mr Clough's sperm from the donor's characteristics. There is no good reason why she should be denied access to Mr Clough's donated sperm if it is still available and available to others.

*Reproducible tissues or gametes are covered by separate legislation in Australia and the United Kingdom.
In relation to sperm retrieval after death, we know Mr Clough wanted children and that he wanted to have children with Ms Baker. We don't know if he wanted her to have his child after his death but that is something we will never know. It seems to be something he did not discuss with anyone. Nevertheless, it can be argued that his consent to organ donation together with his past sperm donation and his wish to have a child with Ms Baker add up to consent for his sperm to be harvested and used by Ms Baker after his death. When Mr Clough donated sperm, we can assume that his permission included giving up any interest in or control over its future use. In other words, he was open to the idea of fathering children in whose lives he had no part. From this and the other things we know, consistency suggests that as well as ticking the organ "donor box $^{\prime \prime 4}$ in his will, if there had been a box specifically requesting permission for his sperm to be harvested after death he would have ticked that too. One of the interesting things about this case is that we seem to be able to work out from Mr Clough's former autonomous decisions what he would want in a situation he did not talk about and might not have contemplated. The evidence we have is a good example of the kind of evidence sought when decisions have to be made for a previously autonomous person who becomes incompetent or debilitatedwhen we want to act in accordance with how that person would choose for him or herself. The surrogate decision makers in this case, Ms Baker and $\mathrm{Mr}$ Clough's family and friends, were sufficiently acquainted with the dead man to 
make a decision reflecting his valuesand there was no disagreement amongst them on this. They were able to show a "demonstrable basis in former autonomous decisions"10 that $\mathrm{Mr}$ Clough would have given his permission for Ms Baker's request for his sperm to be harvested after death.

A further interesting thing about this case is that it illustrates the way in which ethics, law, and personal opinion can differ. My intuitive response to this case was that Ms Baker should not try to have her dead fiancé's baby. Nevertheless, on critical reflection I find there are good reasons in support of her request to retrieve and harvest her fiancé's sperm and no good argument to support my initial response. Ethical reasoning involves critical analysis and (depending on choice of ethical theory), seeking to determine the best outcome from all possible alternatives or looking to see if there are any ethical principles being violated. Legal reasoning is different. In denying Ms Baker's request, the judge relied on precedent as a guide. Legal decisions based on precedent are standardised, consistent, predictable and impersonal, and rooted in the values and ethical standards of the past.

J Med Ethics 2004;30:384-385.

doi: 10.1136/jme.2003.004432

Correspondence to: M Spriggs, Ethics Unit, Murdoch Childrens Research Institute, $\mathrm{RCH}$, Flemington Road, Parkville, Victoria, 3052, Australia; merle.spriggs@mcri.edu.au

\section{REFERENCES}

1 Todd N, Klotz S. Woman loses bid to harvest dead fiancé's sperm. The Age 2003 Jan 7: news section: 6 .

2 Todd N. Woman loses baby plea. Herald Sun. 2003 Jan 7: news section: 4
3 Anon. Woman clings to hope of having dead fiancé's baby. Sydney Morning Herald 2003 Jan 7: http://www.smh.com.au/articles/2003/01/ 07/1041566400161.html (accessed 16 Jan 2004).

4 Gregory J, Moore T, Wilson M. Death and courts end family dream. The Courier-Mail 2003 Jan 7: news section: 1 .

5 Anon. No fatherhood from grave: judge. The Australian 2003 Jan 7: news section: 4.

6 Sullivan D. Justifying postmortem tissue use: ethicolegal foundations Issues paper 11, 1999. Melbourne: The Australian Institute of Health Law and Ethics: 1.

7 Harris J. Rights and reproductive choice. In: Harris J, Holm S, eds. The future of human reproduction: ethics, choice, and regulation. Oxford: Clarendon Press, 1998:5-37.

8 Anon. Fiancée renews baby hope. News Limited 2003 Jan 7: http://www.couriermail.news.com. au/common/story_page/

0,4057,5808064\%255E1702,00.html (accessed 16 Jan 2004). (accessed 8 Jan 2003).

9 Moore T. Second family plan ruined for fiancée. Courier Mail 2003 Jan 8: news section: 6.

10 Beauchamp T, Childress J. Principles of biomedical ethics [5th ed]. New York: Oxford University Press, 2001:98-102.

\section{Commentary}

\section{J Oakley}

c ould it ever be ethically justifiable to remove a dead man's sperm to enable his partner to bear a child to him? If he had clearly indicated his agreement to this in advance, then the posthumous removal of his sperm for this purpose can be ethically justified, particularly in circumstances where the interests of the resulting child can be adequately met. Few dead men would have addressed such a possibility while alive, however, unless they had a specific reason to consider such an issue, perhaps because of a terminal illness. With out a prior indication that removal of his sperm for this purpose would be in accordance with his wishes in such circumstances, the posthumous use of a man's sperm for procreation is unethical.

Posthumously removing organs and tissue from those who have given prior consent to this is commonly thought ethically acceptable. Indeed, some argue that cadaveric organ donation can be ethically justifiable in the absence of an explicit prior directive from the donor, so long as there is reason to believe this to be consistent with the values of the deceased person. Whatever we make of this latter suggestion, however, it does not follow that cadaveric sperm donation is justifiable in similar circumstances.

Deciding on behalf of another (on the basis of their known values) that their organs and tissue will be donated to other patients is one thing, but deciding on behalf of another that they will have offspring raises some significantly different issues. (Of course, some men might regard donating their sperm as akin to the posthumous donation of an unneeded organ, but many men do not view sperm donation in that way.) Indeed, those same values-for example, of personal intimacy-that help justify women's reproductive decisions (regarding access to assisted reproductive technologies and abortion) as being within a protected zone relatively free of state intervention are the values which, for many men, would make being volunteered by another-even one's surviving partner-to have offspring a deeply intrusive practice. $\dagger$

Although procreation may be a fundamental human interest, plenty of fertile people autonomously choose to forgo altogether having children. Someone who thinks, for example, that he would be unable because of other commitments to help raise a child, might believe that his absences would be sufficiently detrimental to any prospective child that he would autonomously choose not to become a parent (even if his partner was willing to carry a disproportionate share of the parenting burdens). If a clinically dead man had such a view, but had not documented in writing that his sperm

† Justice Blackman famously argued, in delivering the opinion of the US Supreme Court in the landmark abortion case of Roe $v$ Wade (1973), that "the Court has recognized that a right of personal privacy, or a guarantee of personal privacy, does exist under the Constitution" and that a line of Supreme Court decisions "make it clear that only personal rights that can be deemed 'fundamental'.... are included in this guarantee of personal privacy. They also make it clear that the right has some extension to activities relating to marriage... procreation...contraception...family relationships... and child rearing and education". was not to be posthumously harvested for reproduction, would it really be justifiable for his surviving partner to harvest his sperm? It does not follow from the fact that a person, while alive, was very keen to have children with his partner that he would have wished his partner to conceive and bear a child to him after his death.

As Spriggs points out, prior to his accidental death in North Queensland, Andrew Clough had expressed a keen desire to have children with his partner Simone Baker. He may also have been a sperm donor in earlier years, and he had given consent for his organs to be donated in the event of his death. Nevertheless, it should not be inferred from these observations that Andrew would have wanted his sperm used by Simone to conceive and bear a child after his death. It is perfectly consistent to want children with one's partner while one is alive, but to prefer that one is not posthumously made a parent after one's death. There can be good reasons for preferring not to become a posthumous parent. As his death was unanticipated, it seems that Andrew did not have occasion to address such a contingency with his partner Simone. Without Andrew's prior authorisation for his sperm to be used for procreation after his death, I believe that the posthumous removal of his sperm for this purpose cannot be ethically justified.

J Med Ethics 2004:30:385. doi: 10.1136/jme.2004.004846

Correspondence to: J Oakley, Centre for Human Bioethics, Monash University, PO Box $11 \mathrm{~A}$, Melbourne 3800, Australia; justin.oakley@arts.monash.edu.au 


\title{
Who owns a dead man's sperm?
}

\section{Cannold}

\author{
A sad outcome, but the right one
}

$\mathrm{T}$ he Brisbane Supreme Court has denied an Australian woman's request to harvest and freeze her dead fiancé's sperm for future impregnation. After she was denied access to the sperm, the woman learnt that her fiancé may have been a sperm donor and she began checking to find out if his sperm was still available. Given what we know, there is a good ethical argument that the woman should not have access to the sperm and have her dead fiance's child. Another aspect of this case is that it illustrates the way in which ethics, law, and personal opinion can differ.

It used to be that when men died, their chance of generating new life went with them. But this is no longer the case. Simone Baker, the woman at the centre of the recent Brisbane Supreme Court Decision, is just one of a growing number of individuals-not just wives, but girlfriends, parents, and even in one case a social worker ${ }^{1}$-who have sought over the last few decades to obtain legal permission to extract, store, and use the sperm of dead men to achieve a pregnancy.

My experience as a bioethicist is that my emotional and rational responses to cases usually coincide. However, in cases like Baker's, I tend to find myself sympathising with the loved ones who seek a dead man's sperm and automatically trusting their motives for doing so. However, on considered reflection, I believe the cases of sperm seekers are invariably weak. In my view, a legitimate decision to grant a sperm seeker access to a dead man's sperm needs to be grounded in a belief that the seeker's access and use of the sperm would not contravene the dead man's autonomy but-through doing what "he would have wanted"-extend it. Such a decision would also need to be based on a clear conviction that in attempting to gain access to the dead man's sperm, the seeker is not using the dead man as a means to their own ends, but both expressing her love for him and attempting, by enabling the birth of his genetic offspring, to pay tribute to him.

If the decision maker does not believe these two things, I believe it would be unjustified for her to grant the seeker access to the dead man's sperm. This is because, in doing so, she would be overriding two important-if not foundational-principles of medical ethics: the prohibition on violating a corpse (or the body of a brain dead person) for reasons other than their own benefit, and the requirement that informed consent be obtained from a person prior to a procedure being undertaken.

Upon reflection, I believe that sperm seekers should not automatically be trusted to be seeking sperm for the right reasons-a desire to extend the dead man's autonomy and not as a means to their own ends-but that they should have to prove that their reasons are right. Because of the circumstances surrounding such cases, I believe it would nearly always be difficult for them to do. This is firstly because when most sperm seekers are making their decisions about (and their case for) the extraction, storage, and/or use of the dead man's sperm, they are in the early stages of grief (there is a window of opportunity of about seven days after the body expires for viable sperm to be extracted). Such grief may make it difficult for the seeker to be clear in their own mind about the precise nature of their motive for seeking the sperm and the existence and/or quality of the evidence to support a contention that recovering the sperm would be what the dead man would have wanted. This lack of clarity would make it difficult for them to persuade others that their reasons for wanting the sperm are sound.

However, this may only be an argument against allowing sperm seekers early use of collected sperm to pursue a child, rather than an argument against their being allowed to collect it now for possible use later. However, when a life partner or son dies, grief typically lasts for many years and part of what is mourned is the loss of the life one expected and wanted to have with the deceased. In the face of such a loss, the bereaved may seek to recover as many aspects of the life they expected and thought they would have-in the case of sperm seekers, one with children in itas they can. Although this is completely understandable, it might be expected to influence the objectivity of the answer the sperm seeker gives to the central question that will and must be answered: in this situation, what would the dead man have wanted?
Typically, sperm seekers claim that their gaining access to the sperm would be what the dead man wanted on the grounds that he had wanted and intended to become a father, and may even have acted in pursuit of this intention. Simone Baker claimed that her fiancé Andrew would have wanted her to have his sperm because the two had intended to have children together and had even decorated a nursery and picked out babies' names. However, to state the often overlooked obvious, it is significantly different for a man to intend to consent to use his sperm to create a child while he is alive and intending to remain that way, than to consent to have his sperm extracted from his dead body, stored, and later used to create a pregnancy. This is not to say that Andrew or any of the other dead men at the centre of such cases necessarily wouldn't have given such consent, but rather that their intended consent, when alive, to becoming a father tells us little about what their views would be on posthumous use of their sperm.

So although I sincerely sympathise with the plight of Simone Baker and sperm seekers like her, I must conclude that the Brisbane Supreme Court's decision to deny her access to her dead finance's sperm was the right one. The only ethical way for sperm seekers in the future to avoid finding themselves in Baker's situation is to discuss with their alive and competent partners or sons now-just as they might discuss organ donation or the terms of a living will-what they would want to happen to their sperm should the unthinkable come to pass.

$J$ Med Ethics 2004;30:386.

doi: 10.1136/jme.2003.004853

Correspondence to: Dr L Cannold, Centre for Applied Philosophy and Public Ethics, University of Melbourne, 3010 Australia; LCannold@unimelb.edu.au

Received 23 June 2003

Accepted for publication 5 August 2003

\section{REFERENCE}

1 McLean SA. Post-mortem human reproduction: legal and other regulatory issues. J Law Med 2002;9:429-37. 


\section{'Til Death Us Do Part: the ethics of postmortem gamete donation}

\section{J Parker}

\section{Couples need to make their wishes explicit if we are to allow postmortem gamete donation}

x her current controversy (see page $x \boldsymbol{x x}$ ) Merle Spriggs discusses the case of Simone Baker and Andrew Clough. ${ }^{1}$ From the day they met in 1997, Simone and Andrew talked about having children. They discussed how many children they would like to have and even picked out names for them. The couple were due to marry on 19 April 2003, but on New Year's Eve 2002 Andrew fell to his death while visiting the Roaring Meg Falls in northern Queensland. At the time both he and Simone were 29 years old. Following his death, Simone made a request to the Brisbane Supreme Court to harvest and freeze Andrew's sperm to enable her to have a child. The request was refused by the court. In refusing the request the judge referred to a law in Queensland making it a criminal offence to "interfere with the body of a dead person without lawful justification".

In discussing cases, bioethicists often proceed swiftly from the 10 line case outline, such as the one above, to analysis in terms of ethical principles. This means that we sometimes miss some of the subtleties and salient moral features of such cases; our subsequent arguments and recommendations being the poorer for it. ${ }^{2}$ The search for a rich understanding of the morally relevant features of cases should play a more central role in analysis and judgement in bioethics than is often the case. This has broad implications for the way we ought to go about "doing ethics". Cases nearly always involve subtle contextual features of real moral significance and this provides good reason for believing that, wherever possible, decisions ought to be made by those who are most closely involved. They are likely in many cases to have a better grasp of these important contextual aspects than any health professional, lawyer, or ethicist. In addition to their greater contextual understanding, further justification for a devolved process of ethical decision making (and of conflict resolution) is provided by the fact it is reasonable to hold that, wherever possible, decisions ought to be made by those who are going to be affected by them. They can be said to have a legitimate interest in the outcome because it is their life that will be affected. These are the people who will have to live with the consequences. In most cases these arguments mean that decisions ought to devolve to individuals. In others where more people are involved, or where there is disagreement, it suggests a deliberative approach to decision making.

The adoption of a devolved and deliberative approach of this kind does not imply that anything goes. The adoption of this approach might be justified in terms of three claims. Firstly, people are usually in the best position to grasp the morally significant features of decisions affecting their own lives. Secondly, the wishes of those affected by a decision ought to be accorded special moral significance in the making of that decision. Thirdly, decisions arising from a process involving, and seen to be reasonable by, those who have a legitimate interest in the outcome, gain legitimacy by virtue of the fact that they have been subjected to "public reason". The reason why not just any decision is acceptable on this account-even if all parties agree-is because these three justifications, combined with a commitment to consistency, require the placing of certain constraints on the deliberative process. The key constraint might be phrased as follows: the outcomes of such a process are justified to the extent that they are themselves consistent with the principles justifying the deliberative approach itself-that is, are conducive to ways of living in which the moral status of those with a legitimate interest in the decision is taken seriously.

What does this mean in the case of Andrew and Simone? What would it mean to take Andrew's legitimate interests in what happens to his body after his death seriously? It seems clear that at the very least an approach of this kind would accord special moral significance to any evidence of Andrew's views about what he did and did not want to happen to his body (and possessions) after his death. For this reason it would be particularly important, in any deliberative analysis of the case, to try to ascertain whether Andrew had in fact previously expressed any such views.
Everything in the lives of Simone and Andrew and of their families before his death had been geared towards their wedding, and to their future family life as a couple. Newspaper reports at the time provide a lot of evidence of Andrew's desire to be a father and to create a family with Simone. He had changed his health insurance to cover "family". He had, with Simone, picked out children's names and turned one of the rooms in their home into a nursery. There can be little doubt that Andrew was looking forward to being married and to living as a family with Simone and their children. Is this also good evidence that he would have wished (had he thought about it) for Simone to have his child after his death? We have good reason to be cautious about this. The sad fact is that, even if Simone were to have his child, despite his wish to be part of a family with Simone and their child, he is not going to be. Despite his wish to get married and see his children in their nursery, this is not going to happen. It is true that there is evidence that Andrew wanted children but this procedure is not going to give him children in the sense he envisaged. There is good reason to doubt whether Andrew had ever contemplated a situation like this (why would he have?) and therefore good reason to be cautious about whether he would in fact have consented to the use of his sperm in these circumstances. It is possible that had he been given the opportunity he would indeed have chosen to consent. He might also however have chosen not to consent (perhaps even on altruistic grounds). We have no evidence either way. My personal position on this (and this may not be relevant) is that I would want my partner, after a suitable period of mourning, to try her best to get on with her life, perhaps finding a new partner. I may be unique in this of course, but I doubt it. There is no evidence that Andrew would have made a similar choice, but neither is there evidence he would not. One thing is certain however, wanting to "become a father" is not the same thing as wanting someone to have one's child after one's death. 
One further piece of evidence related to what Andrew would have wanted that emerged during the court proceedings was the fact that he had been a sperm donor as a student. Surely, it was argued, this implied that he had no objection to his sperm being used by women wanting children and, a fortiori, no objection to his sperm being used to start a pregnancy in Simone. There can be little disagreement with this. It seems reasonable to assume that if the original sperm sample still existed in a usable form there could be no objection to it being used for a pregnancy in Simone, or indeed in anyone else. Unfortunately the original sperm sample no longer exists. Should Andrew's donation of sperm as a student be taken as justification for the postmortem use of sperm extracted from his body? There are several reasons to doubt this. Firstly, donating sperm on one occasion (presumably in the traditional way) cannot in any meaningful sense be said to imply consent to the extraction of sperm from one's body after death. That is, without stretching the concept of consent so far that it becomes meaningless. Secondly, if such consent were to be considered valid it would have a number of interesting implications. It would for example apply to the extraction of sperm from Andrew's body for any woman who wanted it, not only Simone. Applied more widely it would also seem to imply that anyone who had been a sperm donor in life would be available as a sperm donor after deathagain, to any woman who requested it. Presumably this argument would also apply to the harvesting of eggs from deceased women who had in life been egg donors, and so on. This would be likely, at the very least, to make people extremely cautious about making such donations.
The court was also presented with a third, more convincing source of information about Andrew's wishes. For in addition to being a sperm donor as a student, Andrew had also consented to being an organ donor. Could Andrew's consent to "organ donation" be taken to imply his consent to gamete donation? By contrast with his earlier sperm donation, in consenting to organ donation Andrew had clearly been consenting to the invasive use of his body after his death. Might this be said to imply that he would have had no objection to the use of his sperm after his death in the way proposed? A key part of any answer to this question will be a consideration of whether those who complete organ donation forms can be said, on any reasonable interpretation, to be aware of the possibility of the use of their gametes in reproduction, and hence to be providing "informed consent" to this. My suspicion is that this is not the case and that most people who carry such cards currently believe themselves to be (and hence are) consenting solely to the use of their major organsthat is, heart, kidneys, liver, and so on. I suspect therefore that Andrew had not envisaged the possibility that sperm would be extracted from his body and used for assisted reproduction in Simone or in anyone else (for, once again, if valid it would apply to other women in addition to Simone) after his death.

Does this matter? Is it not reasonable to allow the extraction to proceed on the grounds that it is consistent with the spirit of Andrew's consent to organ donation even if not explicitly stated? I think we need to be cautious about this. To the extent that we can be said to have an interest in what happens to our bodies after we die, the way in which our bodies are treated after our death ought to be commensurate both with our explicit wishes and with relevant cultural practices of which we might reasonably be expected to have been aware and to have anticipated. Taken together this implies that the use of the body after death in medicine is only acceptable to the extent that either the person has given explicit and informed consent, or, to the extent that there is broad public awareness and acceptance that this is the way bodies will be treated unless an individual objects.

In the current case neither of these conditions pertains and this would seem to imply that Andrew's sperm ought not to be extracted. If as a society, and as individuals, we wish (as I think we should) to allow the possibility of postmortem gamete donation, we need to encourage couples (and individuals) to discuss these issues and make their wishes explicit, where this is appropriate. At the same time there is a need to encourage a broader public understanding of the issues surrounding organ donation, and to reach agreement about what constitutes good practice in this area.

J Med Ethics 2004;30:387-388.

doi: 10.1136/jme.2003.004945

Correspondence to: Dr M J Parker, The Ethox Centre, University of Oxford, Institute of Health Sciences, Old Road, Headington, Oxford OX3 7LF, UK; Michael.parker@ethox.ox.ac.uk

Received 25 June 2003

Accepted for publication 5 August 2003

\section{REFERENCES}

1 Spriggs M. Woman wants dead fiancé's baby: who owns a dead man's sperm? J Med Ethics 2004;30:384-5.

2 Chambers T. The fiction of bioethics (reflective bioethics). London: Routledge, 1999. 